\title{
Secondary Chromosome Associations and Cytomixis in Corchorus spp.
}

\author{
Aninda Mandal and Animesh K. Datta* \\ Department of Botany, Cytogenetics and Plant Breeding Section, Kalyani University, \\ Kalyani-741235, West Bengal, India
}

Received January 6, 2011; accepted May 20, 2011

\begin{abstract}
Summary Meiotic chromosome behavior (bivalent configurations at diplotene, metaphase I chromosome associations and anaphase I chromosome segregations) including secondary chromosome associations and cytomixis were studied in 2 cultivated (Corchorus capsularis L. and C. olitorius L.) and 6 wild (C. aestuans L., C. fascicularis Lamk., C. pseudocapsularis L., C. pseudoolitorius I. and Z., C. tridens L. and C. trilocularis L.) species of Jute (Family: Tiliaceae). The meiocytes mostly had $2 n=14$ chromosomes (prevalence of rod bivalents, evidenced at diplotene) at MI but in some species notable variation in chromosome numbers was recorded (C. capsularis: $6.94 \mathrm{II}+0.13 \mathrm{I} /$ cell, C. olitorius: $6.79 \mathrm{II}+0.42 \mathrm{I} /$ cell, C. aestuans: $6.86 \mathrm{II}+0.12 \mathrm{I} /$ cell, C. fascicularis: $5.13 \mathrm{II}+1.71 \mathrm{I} /$ cell, C. pseudocapsularis: $6.27 \mathrm{II}+1.45 \mathrm{I} / \mathrm{cell}$, C. pseudoolitorius: $4.83 \mathrm{II}+0.44 \mathrm{I} / \mathrm{cell}$, C. tridens: $6.85 \mathrm{II}+0.30 \mathrm{I} / \mathrm{cell}$, and $C$. trilocularis: $2.85 \mathrm{II}+0.49 \mathrm{I} / \mathrm{cell})$. All AI cells studied showed equal $(7 / 7)$ segregation of chromosomes (excepting C. aestuans $97.56 \%$ and C. fascicularis $98.00 \%$ ) and pollen fertility among the species varied from $37.67 \%$ (C. olitorius) to $84.29 \%$ (C. capsularis). About $15.19 \%$ (C. trilocularis) to $65.22 \%$ (C. tridens) of the PMCs at MI documented secondary association of chromosomes $(2,3,4,5$ and 6 group classes were observed) and secondary polyploidy was attributed as the possible cause. Statistical analysis of cytological data revealed that the basic chromosome number in Corchorus spp. is 4 ( $x=4, n=7$; selected doubling possibly). Preponderance of cytomictic behavior of chromosomes (only in meiosis I) was studied in C. aestuans (hypoploid $1.16 \%$ ), C. fascicularis (hypoploid 12.54\%, hyperploid 2.03\%), C. pseudoolitorius (hypoploid $18.06 \%$, hyperploid 6.94\%) and C. trilocularis (hypoploid 54.43\%, hyperploid $1.27 \%$ ) resulting in numerical variation (only at MI) in chromosome numbers $(n=1,2,3,4,5,6,8,16$ and 18) apart from normal $(n=7)$. Results obtained were discussed and it was presumed that both secondary grouping of chromosomes and cytomixis were the outcomes of genetic consequences.
\end{abstract}

Key words Corchorus spp., Basic chromosome number, Secondary association of chromosomes, Cytomixis, Numerical variation in chromosome numbers.

Study on meiotic chromosome behavior is prerequisite to the formulation of efficient breeding strategies for crop improvement. Reports documenting the meiotic analysis of cultivated Jute (Corchorus capsularis L. and C. olitorius L., yield fibre of commerce; Family: Tiliaceae) as well as in some wild species (C. aestuans L., C. fascicularis Lamk., C. pseudocapsularis L., C. pseudoolitorius I. and Z., C. tridens L. and C. trilocularis L.; important genetic resources for disease resistance-Palve et al. 2004, and fine fibre traits-Mahapatra and Saha 2008; C. trilocularis is identified as tolerant genotype to water inundation-Mahapatra and Saha 2008) suggest that the chromosome number is $2 n=14$ (Rao and Datta 1953, Sharma and Datta 1953, Maity and Datta 2009); although numerical variations (hypoploid and hyperploid) in chromosome number were prevalent among them. Variations in chromosome number were found to occur in natural (C. capsularis, C. olitorius, and C. fascicularis: 4 to 12, even 14 bivalents-Rao and Datta 1953,

\footnotetext{
*Corresponding author, e-mail: dattaanimesh@gmail.com
} 
Sharma and Datta 1953; C. aestuans, C. fascicularis, C. pseudocapsularis and C. pseudoolitorius: $n=1,2,3,4,5,6,9,10$ and 14-Maity and Datta 2009), $\mathrm{F}_{1}$ (C. capsularis $\times$ C. trilocularis-Maity and Datta 2008) and desynaptic (screened from $\mathrm{F}_{6}$ generation of an intervarietal cross of C. capsularis-Basak and Paria 1980) populations; however, the possible cause of such meiotic lability was not clearly identified. Maity and Datta (2008) attributed meiotic instability in $\mathrm{F}_{1}$ hybrid lines of jute as the possible consequence of cytomixis. Further, there are no reports on secondary chromosome association in Corchorus spp. except for an earlier observation made by Nandi (1937) in C. capsularis.

Pairs of bivalents and univalents lying in close proximity but without any distinct material connections were referred to as secondary associations or secondary pairing of chromosomes (Darlington 1965), and the phenomenon was documented firstly in Oryza sativa (Kuwada 1910) and then in Dahlia variabilis (Ishikawa 1911). Since then, it has been encountered in meiotic processes of different plant species (Kempanna and Riley 1964, Sharma and Chatterjee 1966, Gupta and Roy 1973, Agarwal 1983, Sengupta and Datta 2003, Mukherjee and Datta 2005, 2006, Iqbal and Datta 2007, Das et al. 2009, Bhattacharya and Datta 2010) in tracing basic chromosome numbers and the polyploidy nature of the species. The present investigation describes meiotic chromosome behavior documenting secondary chromosome association and cytomixis (cell to cell migration of nuclear materials through cytoplasmic connections-Gates 1911) in Corchorus spp. (C. capsularis, C. olitorius, C. aestuans, C. fascicularis, C. pseudocapsularis, C. pseudoolitorius, C. tridens and $C$. trilocularis) with the objectives to ascertain basic chromosome number and to understand the possible causes of meiotic instability in the studied species.

\section{Materials and methods}

Microsporogenesis was studied in Corchorus spp. (mother seed source of the plant species: C. capsularis-JRC 321, C. olitorius-JRO 524, C. aestuans-WCIJ 088, C. fascicularis-WCIJ 150, C. pseudocapsularis-CIM 036, C. pseudoolitorius-OIN 507, C. tridens-WCIJ 149 and C. trilocularis-KBA 222-from the Central Research Institute for Jute and Allied Fibres, West Bengal, India; plants raised in the Experimental garden of Department of Botany, University of Kalyani, during the months March to October) from fixed young flower buds (6 a.m. to 7 a.m.) of suitable stages of development from 3 to 5 randomly selected plants of each species in Carnoy's solution (6 ethanol: 3 chloroform: 1 acetic acid) and 2 to 3 changes were given in the fixative at the intervals of $24 \mathrm{~h}$. Pollen mother cells (PMCs) and pollen grains obtained from anther squash preparations were stained in $2 \%$ propinocarmine solution. Fully stained pollen grains were considered fertile (Marks 1954). Meiotic data of each species were pooled over the plants and were recorded from diplotene, metaphase I (MI) and anaphase I (AI) cells. Bivalents and univalents were marked as II and I, respectively, in the text. Photomicrographs were taken from temporary squash preparations.

\section{Results}

\section{Chromosomal associations}

Meiocytes in Corchorus spp. had $2 n=14$ chromosomes mostly (Figs. 1-9). Bivalent configuration noted per cell at diplotene (Fig. 1) was predominantly rod (C. capsularis: rings $0.43 \pm 0.07$, rods $6.54 \pm 0.07$, chiasma/cell 7.40 $\pm 0.08,70$ cells scored; C. olitorius: rings $0.48 \pm 0.12$, rods $6.46 \pm 0.08$, chiasma/cell $7.42 \pm 0.08,104$ cells noted; $C$. aestuans: rings $0.53 \pm 0.00$, rods $6.33 \pm 0.06$, chiasma/ cell 7.39 \pm 0.09 , 64 cells observed; $C$. fascicularis rings $0.36 \pm 0.15$, rods $4.71 \pm 0.18$, chiasma/cell $5.42 \pm 0.25,78$ meiocytes estimated; $C$. pseudocapsularis: rings $0.00 \pm 0.00$, rods $5.58 \pm 0.29$, chiasma/ cell 5.58 $\pm 0.29,24 \mathrm{PMCs}$ studied; C. pseudoolitorius: rings $0.32 \pm 0.22$, rods $4.38 \pm 0.19$, chiasma/ cell 4.96 $\pm 0.27,50$ cells scored; $C$. tridens: rings $0.31 \pm 0.00$, rods $6.06 \pm 0.12$, chiasma/cell $6.79 \pm 0.15$, 


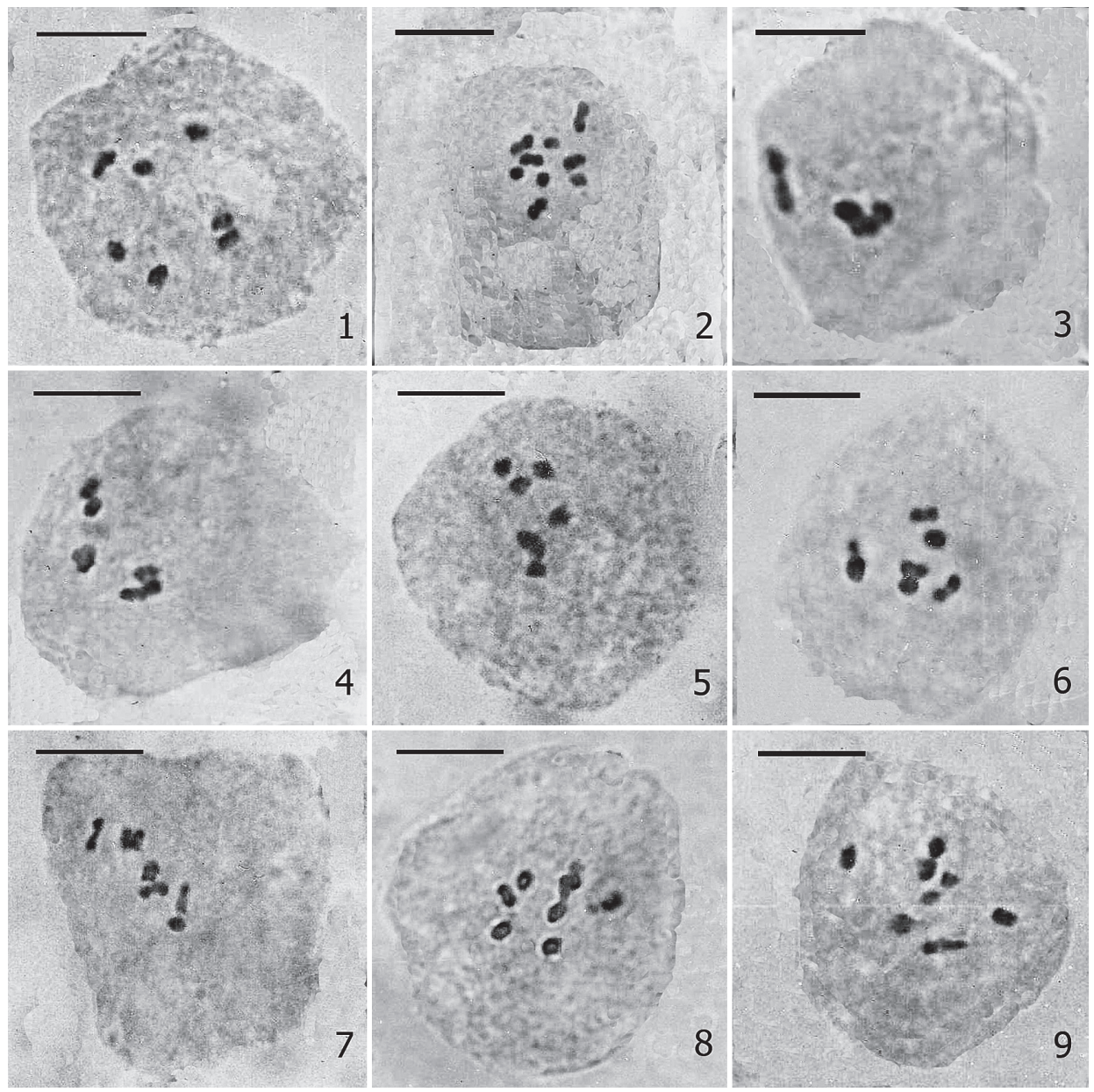

Figs. 1-9. Meiotic metaphase I chromosome (Fig. 1 diplotene) configurations $(2 n=14)$ in Corchorus spp. with secondary groupings (Figs. 3-9). 1: 7 II. 2: $5 \mathrm{II}+4 \mathrm{I} .3$ : $4 \mathrm{II}(1)+3 \mathrm{II}(1)-2$ groups. 4: $3 \mathrm{II}(1)+2 \mathrm{II}(2)-3$ groups. $5: 3 \mathrm{II}(2)+1 \mathrm{II}(1)-3$ groups. $6,7: 2 \mathrm{II}(3)+1 \mathrm{II}(1)-4$ groups. 8 : $3 \mathrm{II}(1)+2 \mathrm{II}(1)+1 \mathrm{II}(3)-5$ groups. $9: 2 \mathrm{II}(1)+2 \mathrm{I}(1)+1 \mathrm{II}(4)-6$ groups. Scale bar $=10 \mu \mathrm{m}$.

96 cells observed; C. trilocularis: rings $0.52 \pm 0.10$, rods $5.38 \pm 0.18$, chiasma/cell $6.42 \pm 0.30,42$ cells scored). In most species univalents were marked in close proximity to each other at diplotene and such juxtaposed arrangements represents the residual attraction between homologues and their very recent separation. Mean chromosome association per cell at MI was $6.94 \mathrm{II}+0.13 \mathrm{I}$ in $C$. capsularis (126 cells scored), $6.79 \mathrm{II}+0.42 \mathrm{I}$ in C. olitorius (86 cells), $6.86 \mathrm{II}+0.12 \mathrm{I}$ in C. aestuans (172 cells), $5.13 \mathrm{II}+1.71 \mathrm{I}$ in $C$. fascicularis (590 cells), 6.27 II+1.45 I in C. pseudocapsularis (22 cells), $4.83 \mathrm{II}+0.44 \mathrm{I}$ in $C$. pseudoolitorius (72 cells), $6.85 \mathrm{II}+0.30 \mathrm{I}$ in $C$. tridens (46 cells) and $2.85 \mathrm{II}+0.49 \mathrm{I}$ in C. trilocularis (158 cells). Formation of 7 II (C. trilocularis-30.38\% to C. capsularis-95.24\%) was predominant in the species. Among the species, C. fascicularis showed variable chromosome associations (7 II-49.49\%, 6 II+2 I-12.71\%, 5 II +4 I-11.36\%-Fig. 2, 4 II+6 I-5.08\%, $3 \mathrm{II}+8 \mathrm{I}-2.03 \%, 2 \mathrm{II}+10 \mathrm{I}-3.22 \%, 1 \mathrm{II}+12 \mathrm{I}-0.34 \%$ and $14 \mathrm{I}-1.19 \%)$. Formation of $14 \mathrm{I}$ was also reported in C. trilocularis $(0.63 \%)$. Bivalents $(p<0.001)$ and univalents $(p<0.001)$ at MI were nonrandomly distributed among the species as evidenced from $\chi^{2}$ test of heterogeneity. All AI cells showed equal (7/7) segregation of chromosomes (excepting: C. aestuans 97.56\%-42 cells scored, 
Table 1. Secondary groupings in Corchorus species

\begin{tabular}{|c|c|c|c|c|c|c|c|c|c|}
\hline \multirow{2}{*}{ Species } & \multirow{2}{*}{$\begin{array}{c}\text { Cells scored } \\
\text { at MI }\end{array}$} & \multirow{2}{*}{$\begin{array}{c}\text { PMC with } \\
\text { secondary } \\
\text { groupings } \\
(\%)\end{array}$} & \multicolumn{5}{|c|}{ PMC (\%) in different group classes } & \multirow{2}{*}{$\begin{array}{l}\chi^{2} \text { value } \\
\text { at } 4 \mathrm{DF}\end{array}$} & \multirow{2}{*}{ Probability } \\
\hline & & & 2 & 3 & 4 & 5 & 6 & & \\
\hline C. capsularis & 126 & 54.76 & 0.00 & 30.43 & 55.07 & 14.49 & 0.00 & 76.85 & $<0.001$ \\
\hline C. olitorius & 86 & 55.81 & 12.50 & 16.67 & 58.33 & 12.50 & 0.00 & 56.90 & $<0.001$ \\
\hline C. aestuans & 172 & 33.72 & 20.69 & 13.79 & 65.52 & 0.00 & 0.00 & 84.41 & $<0.001$ \\
\hline C. fascicularis & 590 & 22.71 & 13.43 & 28.36 & 52.24 & 4.48 & 1.49 & 116.30 & $<0.001$ \\
\hline C. pseudocapsularis & 22 & 27.27 & 0.00 & 0.00 & 66.67 & 33.33 & 0.00 & 10.66 & $<0.05$ \\
\hline C. pseudoolitorius & 72 & 47.22 & 0.00 & 17.65 & 70.59 & 11.76 & 0.00 & 58.35 & $<0.001$ \\
\hline C. tridens & 46 & 65.22 & 13.33 & 20.00 & 60.00 & 6.67 & 0.00 & 33.34 & $<0.001$ \\
\hline C. trilocularis & 158 & 15.19 & 25.00 & 25.00 & 50.00 & 0.00 & 0.00 & 21.00 & $<0.001$ \\
\hline Total & 1272 & 31.68 & 11.41 & 23.08 & 57.57 & 7.44 & 0.50 & 1895.62 & $<0.001$ \\
\hline
\end{tabular}

C. fascicularis $98.00 \%-150$ cells observed; rest showed bridges and laggards). Pollen fertility was recorded to be higher in the cultivated species (C. capsularis $-84.29 \%$ and C. olitorius $-81.18 \%$ ) than wild members (C. aestuans-60.28\%, C. fascicularis-56.67\%, C. pseudocapsularis-62.03\%, C. pseudoolitorius $-63.92 \%$, C. tridens $-70.19 \%$ and C. trilocularis $-37.67 \%$ ).

\section{Secondary chromosomal associations}

Well scattered meiocytes possessing $2 n=14$ chromosomes at MI (Figs. 3-9) were used to study secondary grouping of chromosomes. Bivalents and univalents in the Corchorus spp. tended to form variable groups of 2, 3, 4, 5 and 6, and the frequency of PMCs with secondary groupings ranged from 15.19 to $65.22 \%$ among species and $31.68 \%$ pooled over the species (Table 1). All group classes were only recorded in C. fascicularis. A total of 17 different associations were noted and irrespective of the species $3 \mathrm{II}(1)+2 \mathrm{II}(2)-$ Fig. 4, $3 \mathrm{II}(2)+1 \mathrm{II}(1)-$ Fig. 5 under the 3 group class and $2 \mathrm{II}(3)+1 \mathrm{II}(1)-$ Figs. 6 and 7, $3 \mathrm{II}(1)+2 \mathrm{II}(1)+1 \mathrm{II}(2)$ under the 4 group class were frequent.

The computation of an $\chi^{2}$ test among the different group classes of each Corchorus species (and pooled over the species) revealed heterogeneity (Table 1), thereby suggesting non-random assortment of chromosomes into different group classes but showing preference to the 4 group class. Further, cell frequency of the 4 group class was significantly higher than expected when assessed over the species and it was verified against the total frequency of rest of the group classes (4 group class: observed 232, expected 25.44; rest of the group classes: observed 171, expected 101.76, total $403, \chi^{2}=1895.62$ at $\left.4 \mathrm{DF}, p<0.001\right)$.

\section{Cytomixis and numerical variations in chromosome number}

Cytomixis was evidenced (only in meiosis I) from all microsporophyll squash preparations made in C. aestuans, C. fascicularis, C. pseudoolitorius and C. trilocularis, while the other species showed incipient cytomictic behavior of chromosomes. Different stages (prophase I, MI and AI) were involved in cytomixis (Figs. 10-14). The phenomenon was either restricted between 2 meiocytes (Figs. 11-13) or involving a group (4 to 12) of PMCs (Figs. 10 and 14), resulting in either anucleated cells or with a deficiency in or more chromosomes than normal. Cytomictic connections between meiocytes were observed as chromatin bridges and as cytoplasmic contact between adjacent cells with their common wall dissolved. Mostly, the chromosomes were sticky and agglutinated during the process of cytomixis. PMCs with numerical variations in chromosome number $(n=1,2,3$, 4, 5, 6, 8, 16 and 24-Figs. 15-18) were recorded at MI only in C. fascicularis (hypoploid-12.54\%, hyperploid-2.03\%), C. pseudoolitorius (hypoploid-18.06\%, hyperploid-6.94\%), C. trilocularis (hypoploid-54.43\%, hyperploid-1.27\%) and to a lesser extent in C. aestuans (hypoploid-1.16\%). 

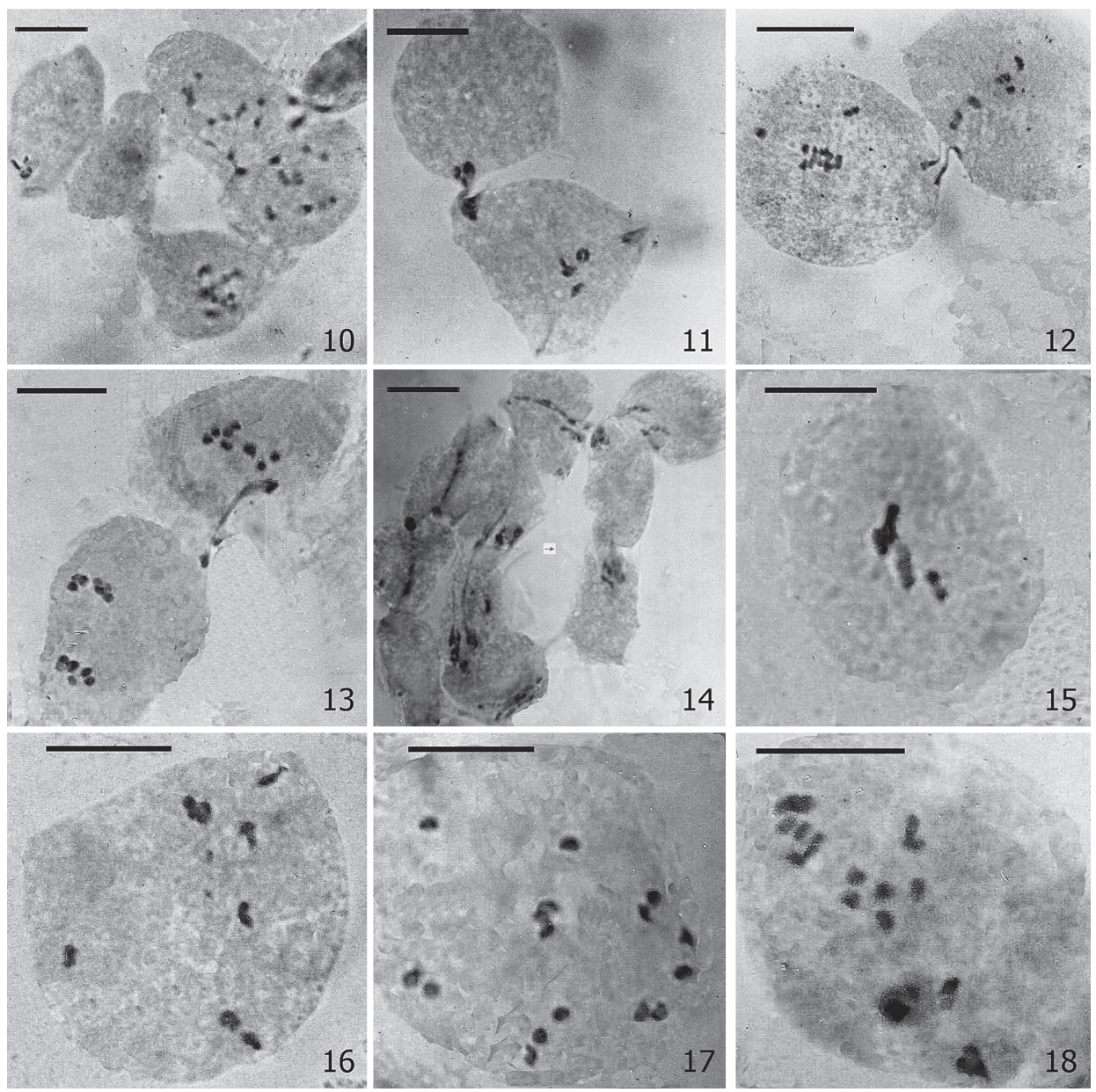

Figs. 10-18. Meiosis in Corchorus spp. showing cytomixis (Figs. 10-14) and hypoploid (Fig. 15) and hyperploid (Figs. 16-18) variation in chromosome numbers (MI). 10: Cytomixis at diplotene involving group of cells. 11: Cytomixis between 2 meiocytes at prophase I. 12: Chromosome transfer at MI. 13: MI and AI cells involved in cytomixis. 14: Cluster of cells in chromatin transfer. 15: 5 II. 16: 8 II. 17: 16 I. 18: 6 II +12 I $(2 n=24)$. Scale bar $=10 \mu \mathrm{m}$.

\section{Discussion}

The persistent occurrence of secondary association of chromosomes in the studied Jute species suggested their secondary polyploidy nature and a statistical analysis of meiotic data revealed that the probable basic chromosome number is 4 (selective doubling of chromosomes possible-as $x=4$ and $n=7$ ). The Corchorus spp. might have undergone cytological diplodization in the course of evolution showing diploid like meiotic behaviour. Rao and Datta (1953) suggested C. fascicularis to be a structural hybrid as a quadrivalent was found to occur frequently in meiocytes. Maity and Datta (2009) reported chromosome association of $0.002 \mathrm{VI}+0.006 \mathrm{IV}+6.98 \mathrm{II}+0.30 \mathrm{I}$ per cell at $\mathrm{MI}$ in $C$. fascicularis. In the present investigation, occurrence of variable numbers of group classes among the species of Corchorus, the formation of different types of chromosomal associations and the total lack of multivalent formations possibly indicated an allopolyploid, rather than autopolyploid, origin of the species. A cytological approach in ascertaining whether a species is auto- or allopolyploid in origin is conventional (Chenuil et al. 1998) but coupled with meiotic data, allozyme mark- 
ers (Olson 1997) and FISH techniques (Lichter 1997) may provide better precision in this regard.

Cytomixis was prevalent in C. aestuans, C. fascicularis, C. pseudoolitorius and C. trilocularis; although other species also showed signs of cytomictic behavior of chromosomes. The phenomenon was exhibited by only a few groups of cells in meiosis I. Datta et al. (2005) were of the opinion that meiocytes present in the microsporangium varied in their cytomictic potential and only those cell clusters which formed during early microsporogenesis and which persisted were possibly signaling the phenomenon of cytomixis. In the present investigation, the existence of cytoplasmic bridges between adjoining PMCs, permitting the transfer of chromatin materials, was noted. Heslop-Harrison (1966) suggested that cytoplasmic channels must exist among meiocytes to facilitate chromatin transfer. Cytomictic channels were reported to be initiated in the preleptotene stage, and to persist throughout prophase, then disappearing before meiosis II (Boldrini et al. 2003). De Nattancourt and Grant (1964) were of the opinion that cytoplasmic bridges were the outcome of premeiotic mitotic division where cytokinesis and karyokinesis were out of phase resulting in incomplete cell wall formation.

The preponderance of cytomixis in C. aestuans, C. fascicularis, C. pseudoolitorius and C. trilocularis possibly induced numerical variation in chromosome numbers. Such variations were only studied at MI, thereby indicating that the aberrant meiocytes fail to survive beyond this stage; although pollen fertility in these species seems to be affected. However, meiotic lability reported earlier in C. capsularis and C. olitorius (Datta 1953, Rao and Datta 1953) and C. pseudocapsularis (Maity and Datta 2008) could not be explained as in the present investigation the species uniformly documented $2 n=14$ chromosomes in their meiocytes. The evolutionary significance of cytomixis in the origin of aneuploids and polyploids was emphasized (Sarvella 1958, Omara 1976, Datta and Biswas 1984, Falistocco et al. 1995) but it seems rather difficult to justify from the results of the present findings. The origin of cytomixis is still fairly unknown (Boldrini et al. 2003) but cytomixis is documented in cytologically unbalanced plants like haploids, triploids, aneuploids and apomicts more often than in normal diploids (Nirmala and Rao 1996). In this context, it would be relevant to mention that Ocimum spp. (Mukherjee and Datta 2005, 2006) and Withania somnifera (Iqbal and Datta 2007) were secondary polyploids with concomitant occurrence of persistent cytomictic behavior of chromosomes (Datta et al. 2005), but that Sesamum indicum (Sengupta and Datta 2003) and Uraria picta (Bhattacharya and Datta 2010) were also secondary polyploids but showed no sign of cytomixis. However, it would be logical to suggest that plant species with disturbed genetical backgrounds may possess some sort of genomic constraint(s) which may account for cytomixis. Maity and Datta (2008) suggested that cytomixis was evident in all $\mathrm{F}_{1}$ hybrid lines, including the female parent (C. trilocularis-female $\times$ C. capsularis-male), thereby indicating the possible genetic inheritance of the phenomenon. Zheng et al. (1987) correlated cytomixis with different genotypic modifications. Soodan and Wafai (1987) presumed the involvement of specific genes for cytomixis which express only under particular environmental conditions. Thus, it may be inferred that both secondary groupings and cytomictic behavior of chromosomes were possibly the outcomes of genetic consequences.

\section{Acknowledgements}

This research is grant aided by UGC (India).

\section{References}

Agarwal, P. K. 1983. Secondary association of bivalents in Cissus discolor blume. Cytologia 48: 577-580.

Basak, S. L. and Paria, P. 1980. Desynapsis and spontaneous trisomy in jute (Corchorus olitorius L.). Theor. Appl. Genet. 56: $253-256$. 
Bhattacharya, A. and Datta, A. K. 2010. Secondary chromosome association in Uraria picta (Jacq.) DC (Family: Leguminosae). Cytologia 75: 37-40.

Boldrini, K. R., Bione N. C. P. and Pagliarini, M. S. 2003. Chromosome transfer among pollen mother cells of garden cotton (Codiaeum variegatum Blume). Cytologia 68: 341-344.

Chenuil, A., Galtier, N. and Berreb, P. 1998. A test of hypothesis of an autopolyploid $v s$. allopolyploid origin for a tetraploid lineage: application to the genus Barbus (Cyprinidae). Heridity 82: 373-380.

Darlington, C. D. 1965. Recent Advances in Cytology (vol.2). Churchill, London, p. 671.

Das, A., Datta, A. K. and Ghose, S. 2009. Cytogenetical studies on two varities of Withania somnifera. J Trop Med Plants 10: 249-256.

Datta, R. M. 1953. Meiosis in Corchorus spp. Sci Cult 18: 385-385.

Datta, A. K. and Biswas, A. K. 1984. Cytomixis and a trisomic in Nigella sativa L. Cytologia 49: 437-445.

-, Mukherjee, M. and Iqbal, M. 2005. Persistent cytomixis in Ocimum basilicum L. (Lamiaceae) and Withania somnifera (L.) Dun. (Solanaceae). Cytologia 70: 309-313.

de Nattancourt, D. and Grant, W. F. 1964. La cytogenetics de Lotus (Leguminosae) III. Un cas de cytomixie dans un hybride interspecifique. Cytologia 29: 191-195.

Falistocco, E., Tosti, N. and Falcinelli, M. 1995. Cytomixis in pollen mother cells of diploid Dactylis, one of the origin of $2 n$ gametes. J. Hered. 86: 448-453.

Gates, R. R. 1911. Pollen formation in Oenothera gigas. Ann. Bot. 25: 909-940.

Gupta, P. P. and Roy, S. K. 1973. Primary and secondary chromosome association in Euryle ferox Salisb. Cytologia 38: 645-649.

Heslop-Harrison, J. 1966. Cytoplasmic connections between angiosperm meiocytes. Ann. Bot. 30: 221-230.

Iqbal, M. and Datta, A. K. 2007. Cytogenetic studies in Withania somnifera (L.) Dun. (Solanaceae). Cytologia 72: $43-47$.

Ishikawa, M. 1911. Cytologische Studien von Dahlien. Botanical Magazine Tokyo. 25: 1.

Kempanna, C. and Riley, R. 1964. Secondary association between genetically equal bivalents. Heredity 19: $289-299$.

Kuwada, Y. 1910. A cytological study of Oryza sativa L. Botanical Magazine Tokyo 24: 267-281.

Lichter, P. 1997. Multicolour FISHing: What's the catch? Trends Genet. 13: 475-478.

Mahapatra, A. K. and Saha, A. 2008. Genetic resources of jute and allied Fibers crops. Jute and allied Fibers updates: production and technology. Barrackpore, Kolkata. p. 327.

Maity, S. and Datta, A. K. 2008. Cytomorphological studies in $\mathrm{F}_{1}$ hybrids (Corchorus capsularis $\mathrm{L} . \times$ Corchorus olitorius $\mathrm{L}$.) of jute (Tiliaceae). Comp Cytogenet 2: 143-149.

— and - 2009. Meiosis in nine species of Jute (Corchorus). Indian J. Sci. Technol. 2: 27-29.

Marks, G. E. 1954. An aceto-carmine glycerol jelly for use in pollen-fertility counts. Biotech Histochem 29: 277-278.

Mukherjee, M. and Datta, A. K. 2005. Secondary chromosome associations in Ocimum basilicum L. and Ocimum tenuiflorum L. Cytologia 70: 149-152.

— and - 2006. Secondary Chromosome Associations in Ocimum spp. Cytologia 71: 149-152.

Nandi, H. K. 1937. Trisomic mutation in jute. Nature 140: 973-974.

Nirmala, A. and Rao, P. N. 1996. Genesis of chromosome numerical mosicism in higher plants. Nucleus 39: 151-175.

Olson, M. 1997. Bayesian procedures for discriminating among hypotheses with discrete distributions: inheritance in the tetraploid Astilbe biternata. Genetics 147: 1933-1942.

Omara, M. K. 1976. Cytomixis in Lolium parenne. Chromosoma 55: 267-271.

Palve, S. M., Sinha, M. K., and Chattopahdyay, S. 2004. Genetic variability for fiber strength and fitness in wild relatives of genus Corchorus. Proc. Nat. Seminar on diversified uses of Jute and Allied Fiber Crops, Barrackpore, Kolkata. p. 178.

Rao, N. S. and Datta, R. M. 1953. Chromosomes of the genus Corchorus. Nature 13: 754.

Sarvella, P. 1958. Cytomixis and the loss of chromosomes in meiotic and somatic cells of Gossypium spp. Cytologia 23: $14-24$.

Sharma, A. K. and Chatterjee, A. K. 1966. Cytological studies on orchids with respect to their evolution and affinities. Nucleus 9: 177-203.

Sharma, M. S. and Datta, R. M. 1953. Complex chromosome mosaic and variable microsporocytes in C. capsularis L. Sci Cult 10: 202-203.

Sengupta, S. and Datta, A. K. 2003. Secondary chromosome associations in control and mutant plant types of Sesamum indicum L. Cytologia 68: 141-145.

Soodan, A. S. and Wafai, B. A. 1987. Spontaneous occurrence of cytomixis during microsporogenesis in Almond (Prunus amygdalus Batsch) and Peach (P. persica Batsch). Cytologia 52: 361-364.

Zheng, G. C., Yang, Q. and Zheng, Y. 1987. The relationship between cytomixis, chromosome mutation and karyotype evolution in Lily. Caryologia 40: 243-259. 